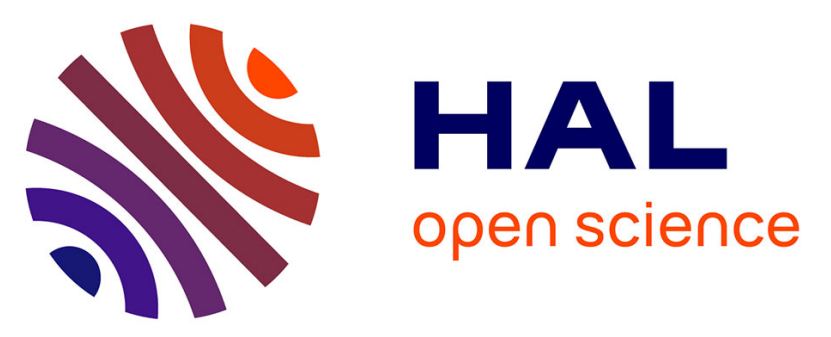

\title{
Contrasting weed species composition in perennial alfalfas and six annual crops: implications for integrated weed management
}

\author{
Helmut Meiss, Safia Mediene, Rainer Waldhardt, Jacques Caneill, Nicolas \\ Munier-Jolain
}

\section{To cite this version:}

Helmut Meiss, Safia Mediene, Rainer Waldhardt, Jacques Caneill, Nicolas Munier-Jolain. Contrasting weed species composition in perennial alfalfas and six annual crops: implications for integrated weed management. Agronomy for Sustainable Development, 2010, 30 (3), pp.657-666. 10.1051/agro/2009043 . hal-00886552

\section{HAL Id: hal-00886552 https://hal.science/hal-00886552}

Submitted on 1 Jan 2010

HAL is a multi-disciplinary open access archive for the deposit and dissemination of scientific research documents, whether they are published or not. The documents may come from teaching and research institutions in France or abroad, or from public or private research centers.
L'archive ouverte pluridisciplinaire HAL, est destinée au dépôt et à la diffusion de documents scientifiques de niveau recherche, publiés ou non, émanant des établissements d'enseignement et de recherche français ou étrangers, des laboratoires publics ou privés. 


\title{
Contrasting weed species composition in perennial alfalfas and six annual crops: implications for integrated weed management
}

\author{
Helmut MEISs ${ }^{1,2}$, Safia MÉdiÈnE $^{3}$, Rainer WALDHARdT $^{2}$, Jacques CANEILL $^{1}$, Nicolas MUNIER-JOLAIN ${ }^{1 *}$ \\ ${ }^{1}$ Institut National de la Recherche Agronomique (INRA), UMR 1210 Biologie et Gestion des Adventices, INRA / ENESAD / Université de Bourgogne, \\ 17 rue Sully, BP 86510, 21065 Dijon Cedex, France \\ ${ }^{2}$ Institute of Landscape Ecology and Resources Management, Division of Landscape Ecology and Landscape Planning, Justus-Liebig-University Giessen, IFZ, \\ Heinrich-Buff-Ring 26-32, 35392 Giessen, Germany \\ ${ }^{3}$ AgroParisTech, UMR 211 INRA-AgroParisTech, BP 01, 78850 Thiverval-Grignon, France
}

(Accepted 9 October 2009)

\begin{abstract}
Weed communities are most strongly affected by the characteristics and management of the current crop. Crop rotation may thus be used to prevent the repeated selection of particular weed species. While weed communities are frequently compared among annual crops, little is known about the differences between annual and perennial crops that may be included in the rotations. Moreover, nearly all existing studies (17 articles reviewed) are based on local field experiments rather than commercial fields. We compared the weed composition in perennial alfalfas (Medicago sativa) and six annual crops: winter wheat (Triticum aestivum), oilseed rape (Brassica napus), pea (Pisum sativum), sunflower (Helianthus annuus), maize (Zea mays) and sorghum (Sorghum bicolor) using data from 632 commercial fields in western France. Weed species composition showed the strongest dissimilarities between perennial alfalfas and all annual crops, followed by the well-known differences between autumn- and spring/summer-sown annual crops. Indicator Species Analysis showed that most weed species either preferred perennial alfalfas (including Taraxacum officinale, Veronica persica, Crepis spp., Poa trivialis, Silene latifolia, Capsella bursa-pastoris and Picris spp.) or annual crops (including Mercurialis annua, Galium aparine, Fallopia convolvulus, Chenopodium album and Cirsium arvense). Perennial alfalfas thus suppressed many weeds that are widespread (and sometimes problematic) in annual crops while favouring other species. Shifted weed composition and reduced frequency of several noxious weeds suggest that perennial alfalfas may be used as a valuable part of integrated weed management, reducing the need for herbicides and sustaining plant and animal diversity in agricultural landscapes.
\end{abstract}

crop diversification / temporary grassland / perennial forage crop / alfalfa / Medicago sativa / plant community composition

\section{INTRODUCTION}

Weed communities in arable fields are mainly characterised by the current crop type and associated farming practices (Doucet et al., 1999). These anthropogenic factors are probably more important than environmental factors linked to, e.g., soil type and climate (Fried et al., 2008). Each crop and associated management practices provide more or less specific conditions that act as filters (sensu Belyea and Lancaster, 1999) offering different ecological niches for weeds. Rotating dissimilar crops constitutes an important part of preventative weed management (Liebman and Dyck, 1993; Bellinder et al., 2004; Nazarko et al., 2005; Smith and Gross, 2007). It may avoid selection for, and rapid population increases in, particular weed species adapted to one crop type, such as may

* Corresponding author: munierj@dijon.inra.fr happen when one crop is cultivated during consecutive years ('monoculture').

Doucet et al. (1999) tried to disentangle the effects of intrinsic crop characteristics and crop management practices on weeds. They concluded that management had stronger influences than crop characteristics; however, both are often closely associated. First, the crop type influences several management practices important for weeds including the sowing season, the usable types of (selective) herbicides, the possibilities of mechanical weed control in the crop, and the harvesting date (determining, e.g., the potential for weed seed production). Second, several management practices (e.g., sowing date and density, fertilisation, irrigation, pest control) affect crop growth dynamics and thus crop-weed competition.

The 'weed-regulating function' of crop rotations may, however, be restricted if crop types and management practices are too similar or if the rotations are too short. To avoid this 
situation, crop rotations should be diversified. One possibility may be the introduction of perennial crops such as alfalfa/lucerne (Medicago sativa), clovers (Trifolium spp.), other legumes (Fabaceae), grasses (e.g. Dactylis glomerata, Festuca spp., Lolium spp., Phleum pratense, Poa pratensis) and various legume-grass mixtures (Freyer, 2003). Such crops are also called 'temporary grasslands', 'leys', 'sod crops', 'fodder crops' or 'hay crops'. Such perennial crops stay on the field for several years before being converted to annual crops again. They are mostly used for livestock forage production, but may also be used to produce energy or raw material for industries (Tilman et al., 2006). The amelioration of soil fertility and the regulation of pest and weed infestations are further reasons for interrupting sequences of annual crops with temporary grasslands (Katsvairo et al., 2006). The appearance of cheap fertilisers and pesticides and the separation of crop and livestock production are the main reasons for the decline in temporary grasslands in conventional cropping systems of many regions (Freyer, 2003). Today, temporary grasslands are mainly used in organic or low-input cropping systems. The need for improving the sustainability of cropping systems has recently increased the interest in diversifying farming systems with perennial crops (Katsvairo et al., 2006).

Perennial crops may have strong impacts on the weed composition. Compared with annual crops, perennial forage crops are characterised by (a) reduced soil disturbances due to the absence of soil tillage for the whole duration of the crop (about 2-6 years), (b) increased aboveground disturbances caused by frequent hay cuttings ( $1-5$ times per year) or grazing, (c) high and temporally extended competition caused by permanent and intense canopy closure and deep and dense rooting systems, (d) reduced or omitted herbicide use (Bellinder et al., 2004), and possibly (e) allelopathic compounds released by some perennial crops including alfalfa (Khanh et al., 2005). These characteristics may have various direct and indirect impacts on weeds. Established weed plants may benefit from the absence of soil tillage and from the reduced herbicide use. In contrast, they may suffer from the high competition (Schoofs and Entz, 2000) and from the regular cuttings (Norris and Ayres, 1991; Meiss et al., 2008). Cuttings may temporally reduce the competition for light, but regrowth of forage crops is generally fast (Gosse et al., 1988; Meiss et al., 2008) and belowground competition for nutrients and water remains strong. The absence of soil tillage and the permanent vegetation cover may cause an accumulation of plant litter that may form a weed-suppressive mulch. In perennial crops, soil characteristics (organic matter, humidity, nutrients) and microclimatic conditions (temperature, light quantity and quality) relevant to weeds may be different to annual crops (Entz et al., 2002). Therefore, some weed species may not be able to germinate without soil disturbance (Huarte and Arnold, 2003), and a delayed nitrogen availability in legume-based cropping systems (in contrast to mineral $\mathrm{N}$ fertilisation) may favour species with larger seeds over smaller seeds (Liebman and Davis, 2000). Finally, the absence of soil tillage and the permanent vegetation cover may favour weed seed decay or seed predation by animals (Westerman et al., 2005). All these factors may potentially change weed demography and species composition in perennial forage crops. However, differences between annual and perennial crops are poorly documented, in contrast to comparisons between annual crops (Doucet et al., 1999; Murphy et al., 2006; Fried et al., 2008). Available empirical studies analysing the effects of forage crops on weeds are summarised in Table I.

Most of the studies report reduced seed or plant abundance of several noxious weeds at the end of the forage crops or in the following crop. Disadvantaged species include mostly annual dicotyledonous species such as Abutilon theophrasti, Amaranthus spp., Brassica kaber and Galium aparine, but also some problematic annual grasses such as Apera spica-venti and Avena fatua, and a few perennial weeds such as Cirsium arvense. Meanwhile, several studies indicate that other species may profit from the forage crops including perennial broad-leaved weeds such as Taraxacum officinale and Rumex spp., some annual broad-leaved species such as Thlaspi arvense and some grasses such as Elymus repens and Poa spp. (see references in Tab. I). For several weed species, different studies report variable or even contradictory results (Tab. I).

Most available studies were based on local field experiments, whereas only one study was conducted on a larger number of fields from commercial farms (Ominski et al., 1999). Moreover, many studies refer to forage crops lasting only 1 year (Tab. I), but impacts on weeds may differ in pluri-annual forage crops. Ten out of the 17 available studies concerned North America (Tab. I) but agronomic practices and environmental conditions may be different elsewhere.

The aim of this study was to compare the weed species composition in perennial and annual crops. The current crop is known to have a strong impact on the expressed weed composition. Effects of preceding crops, which have probably the second most important influence on weed communities (Fried et al., 2008), will be studied elsewhere. We used data from $>600$ commercial fields in western France including the most frequent perennial crop, alfalfa/alfalfa (Medicago sativa), and six annual crops: winter wheat (Triticum aestivum), oilseed rape (Brassica napus), pea (Pisum sativum), sunflower (Helianthus annuus), maize (Zea mays) and sorghum (Sorghum bicolor). This study might provide additional knowledge about the potential of perennial crops to contribute to a more sustainable weed management in cereal-based cropping systems.

\section{MATERIALS AND METHODS}

\subsection{Data sampling}

The field surveys were conducted in a region of intensive agriculture in western France $\left(46^{\circ} 11^{\prime} \mathrm{N}, 0^{\circ} 28^{\prime} \mathrm{W}\right)$. Annual mean precipitation is $779 \mathrm{~mm}$ and mean temperature $12.3{ }^{\circ} \mathrm{C}$ (5.6 in winter, 18.9 in summer). The commercial fields were part of a large study area $\left(400 \mathrm{~km}^{2},>18000\right.$ fields) supporting research on agriculture and biodiversity since 1994 . Weeds were observed in spring and early summer of the years 2006, 2007 and 2008. We compared seven major crop species (see Tab. II for crop names and survey dates). The number of analysed fields per crop roughly corresponded to the relative 
Table I. Overview of studies investigating the impacts of temporary grasslands (also termed 'hay crops', 'forage crops', 'sod crops', 'leys') on weeds.

\begin{tabular}{|c|c|c|c|c|c|c|}
\hline Reference & $\begin{array}{c}\text { Type of } \\
\text { study }^{1} \text { (total } \\
\text { duration) }\end{array}$ & Location & $\begin{array}{l}\text { Crops or rotations } \\
\text { compared }^{2} \text { (forage } \\
\text { crop durations) }\end{array}$ & Main findings & $\begin{array}{c}\text { Species } \\
\text { suppressed }\end{array}$ & $\begin{array}{l}\text { Species } \\
\text { favoured }\end{array}$ \\
\hline $\begin{array}{l}\text { Norris and } \\
\text { Ayres, } 1991\end{array}$ & FE (3y) & $\begin{array}{l}\text { California, } \\
\text { USA }\end{array}$ & $\begin{array}{l}\text { Alfalfa (?), cutting } \\
\text { frequency: } 25,31 \\
\text { or } 37 \text { days }\end{array}$ & $\begin{array}{l}\text { Foxtail invasion decreased with } \\
\text { increasing cutting interval }\end{array}$ & Setaria glauca & \\
\hline $\begin{array}{l}\text { Entz et al., } \\
1995\end{array}$ & $\begin{array}{l}\text { Interview of } \\
253 \text { farmers }\end{array}$ & $\begin{array}{l}\text { Manitoba, } \\
\text { Canada }\end{array}$ & $\begin{array}{l}\text { annual crops after } \\
\text { perennial forages } \\
(\sim \mathbf{3}-\mathbf{7 y})\end{array}$ & $\begin{array}{l}\text { "Weed control benefits" reported } \\
\text { by } 83 \% \text { of farmers, lasting } \\
\text { for } 1 \mathrm{y}, 2 \mathrm{y} \text {, or more after } \\
\text { forages (11\%, } 50 \% \text { and } 33 \% \text { of } \\
\text { respondents), higher crop yields }\end{array}$ & & \\
\hline $\begin{array}{l}\text { Andersson } \\
\text { and Milberg, } \\
1996,1998\end{array}$ & FE (26y) & $\begin{array}{l}\text { Southern } \\
\text { Sweden }\end{array}$ & $\begin{array}{l}\text { 6y rotations with } \\
\text { (i) grass ley } \\
\text { (2y) } \\
\text { (ii) legume-grass } \\
\text { ley }(2 y) \text {, } \\
\text { (iii) spring wheat } \\
+ \text { fallow }\end{array}$ & $\begin{array}{l}\text { Strong community differences } \\
\text { between ley and all annual crops, } \\
\text { but not between } 3 \text { rotations, } \\
\text { no weed problems (herbicides } \\
\text { used in cereals only) }\end{array}$ & $\begin{array}{l}\text { Many annual } \\
\text { weeds }\end{array}$ & $\begin{array}{l}\text { T. officinale, } \\
\text { Cerastium } \\
\text { fontanum, } \\
\text { Poa annua }\end{array}$ \\
\hline $\begin{array}{l}\text { Gill and } \\
\text { Holmes, } \\
1997\end{array}$ & $\begin{array}{l}\text { Review of } \\
\text { FE }\end{array}$ & $\begin{array}{l}\text { Southern } \\
\text { Australia }\end{array}$ & $\begin{array}{l}\text { mown or grazed } \\
\text { pastures }(\mathbf{2}-\mathbf{3 y}) \\
\text { included in cereal } \\
\text { rotations }\end{array}$ & $\begin{array}{l}\text { Grazing or cutting for hay } \\
\text { or green manure help } \\
\text { control weeds including } \\
\text { herbicide-resistant Lolium sp. } \\
\text { Lower weed seed production }\end{array}$ & $\begin{array}{l}\text { Lolium spp., } \\
\text { Avena fatua, }\end{array}$ & \\
\hline $\begin{array}{l}\text { Clay and } \\
\text { Aguilar, } \\
1998\end{array}$ & FE (3y) & $\begin{array}{l}\text { South } \\
\text { Dakota, } \\
\text { USA }\end{array}$ & $\begin{array}{l}\text { corn after (i) corn, } \\
\text { (ii) alfalfa ( } 2 \mathbf{y})\end{array}$ & $\begin{array}{l}\text { Decreasing weed biomass } \\
\text { during forage phase and } \\
\text { in corn after alfalfa, } \\
\text { same seed bank density but } \\
\text { higher } \% \text { of grasses, higher } \\
\text { corn yield, variable seed } \\
\text { density \& emergence } \\
\text { depending on input } \\
\text { level }\end{array}$ & $\begin{array}{l}\text { Broad-leaved } \\
\text { species, some } \\
\text { grasses }\end{array}$ & $\begin{array}{l}\text { Some } \\
\text { other } \\
\text { grasses }\end{array}$ \\
\hline $\begin{array}{l}\text { Ominski } \\
\text { et al., } \\
1999\end{array}$ & $\begin{array}{l}\text { Surveys in } \\
117 \\
\text { commercial } \\
\text { fields }(2 \mathrm{y})\end{array}$ & $\begin{array}{l}\text { Manitoba, } \\
\text { Canada }\end{array}$ & $\begin{array}{l}\text { cereals after } \\
\text { (i) alfalfa- } \\
\text { grasses (?) } \\
\text { (ii) cereals }\end{array}$ & $\begin{array}{l}\text { Reduced overall weed } \\
\text { densities, weed } \\
\text { community shifts }\end{array}$ & $\begin{array}{l}\text { Avena fatua, } \\
\text { Cirsium arvense, } \\
\text { Brassica kaber, } \\
\text { Galium aparine }\end{array}$ & $\begin{array}{l}\text { Taraxacum } \\
\text { officinale, } \\
\text { Thlaspi } \\
\text { arvense }\end{array}$ \\
\hline $\begin{array}{l}\text { Schoofs } \\
\text { and Entz, } \\
2000\end{array}$ & $\mathrm{FE}(2 \mathrm{y})$ & $\begin{array}{l}\text { Manitoba, } \\
\text { Canada }\end{array}$ & $\begin{array}{l}\text { peas after } \\
\text { (i) forages (1y), } \\
\text { (ii) wheat }\end{array}$ & $\begin{array}{l}\text { Herbicide-free forages } \\
\text { suppressed grass weeds as } \\
\text { effective as sprayed wheat, } \\
\text { variable effect on broad- } \\
\text { leaved weeds (not enough } \\
\text { competition), higher pea } \\
\text { yields after forages but } \\
\text { some herbicides } \\
\text { necessary in peas }\end{array}$ & $\begin{array}{l}\text { Avena fatua, } \\
\text { Setaria viridis }\end{array}$ & \\
\hline $\begin{array}{l}\text { Sjursen, } \\
2001\end{array}$ & $\mathrm{FE}(8 \mathrm{y})$ & $\begin{array}{l}\text { Fryden- } \\
\text { haug, } \\
\text { Norway }\end{array}$ & $\begin{array}{l}\text { 6-y rot. including } \\
\text { (i) grass-clover } \\
\text { ley }(3 y) \text {, } \\
\text { (ii) annual crops } \\
\text { (with } \\
\text { undersowing) }\end{array}$ & $\begin{array}{l}\text { Same seed bank diversity } \\
\text { but lower established } \\
\text { diversity }\end{array}$ & $\begin{array}{l}\text { Annual } \\
\text { broad-leaved }\end{array}$ & $\begin{array}{l}\text { Perennial } \\
\text { broad-leaved }\end{array}$ \\
\hline
\end{tabular}


Table I. Continued.

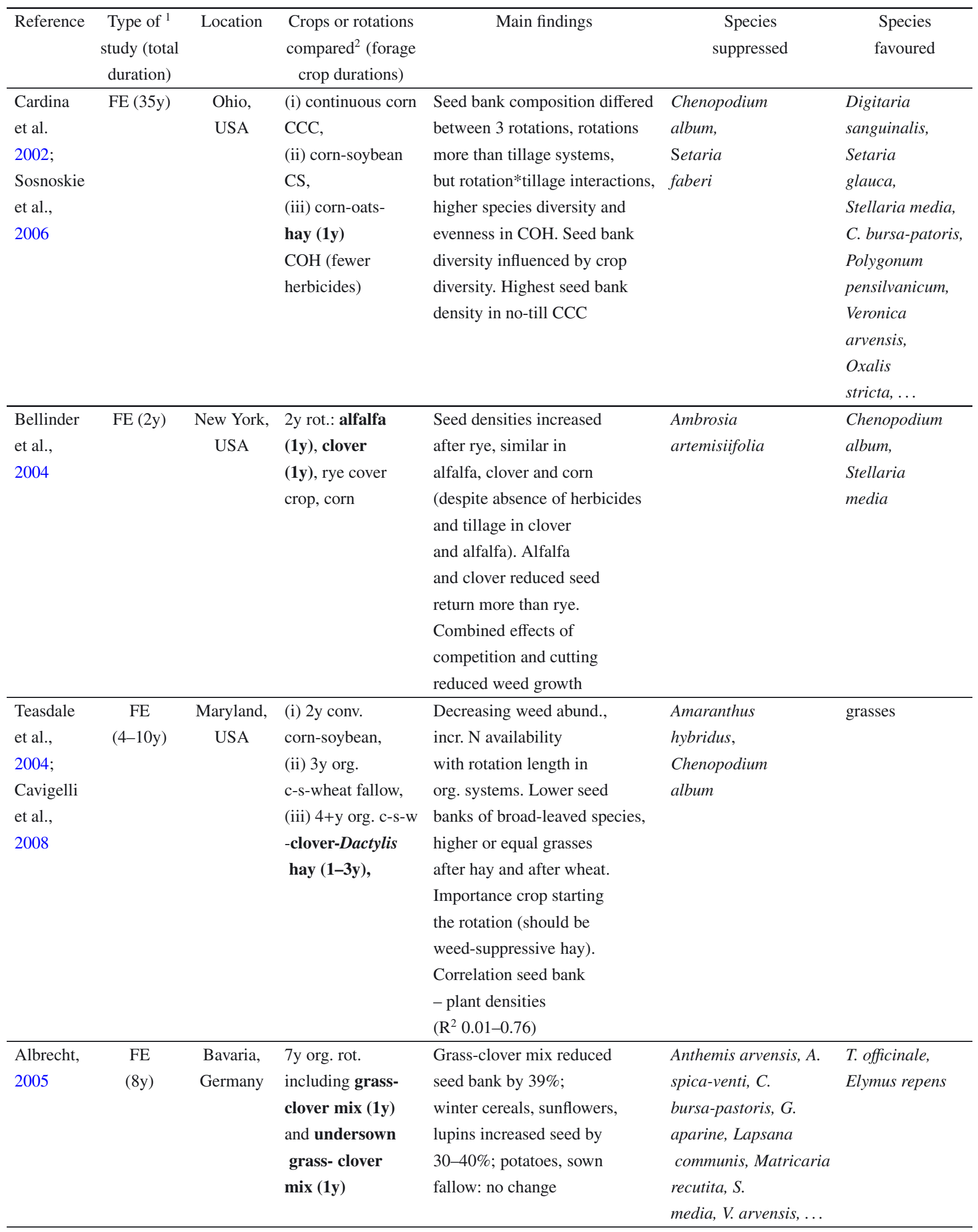


Table I. Continued.

\begin{tabular}{|c|c|c|c|c|c|c|}
\hline Reference & $\begin{array}{c}\text { Type of }{ }^{1} \\
\text { study (total } \\
\text { duration) }\end{array}$ & Location & $\begin{array}{l}\text { Crops or rotations } \\
\text { compared }^{2} \text { (forage } \\
\text { crop durations) }\end{array}$ & Main findings & $\begin{array}{c}\text { Species } \\
\text { suppressed }\end{array}$ & $\begin{array}{c}\text { Species } \\
\text { favoured }\end{array}$ \\
\hline $\begin{array}{l}\text { Heggen-Staller } \\
\text { and Liebman, } \\
2006\end{array}$ & $\begin{array}{l}\mathrm{FE} \\
(5 \mathrm{y})\end{array}$ & $\begin{array}{l}\text { Iowa, } \\
\text { USA }\end{array}$ & $\begin{array}{l}\text { (i) } 2-y \text { : maize-soybean, } \\
\text { (ii) 3-y: m-s-triticale+ } \\
\text { red clover (1y), } \\
\text { (iii) 4-y: m-s-triticale } \\
\text { +alfalfa- } \\
\text { alfalfa (1.5y) }\end{array}$ & $\begin{array}{l}\text { Low A. theophrasti } \\
\text { seedling survival + } \\
\text { fecundity in alfalfa, } \\
\text { higher seedling survival } \\
+ \text { fecundity in maize + } \\
\text { soybean in } 3 \text { - and } \\
\text { 4-y rot ( } 75 \% \text { less } \\
\text { herbicides), but pops } \\
\text { remained stable. } \\
\text { Setaria faberi } \\
\text { increased in } 1 \text { study year }\end{array}$ & $\begin{array}{l}\text { Abutilon } \\
\text { theophrasti }\end{array}$ & $\begin{array}{l}\text { Setaria } \\
\text { faberi }\end{array}$ \\
\hline $\begin{array}{l}\text { Hiltbrunner } \\
\text { et al., } \\
2008\end{array}$ & $\begin{array}{c}\mathrm{FE} \\
(15 \mathrm{y})\end{array}$ & $\begin{array}{l}\text { Albertswil, } \\
\text { Switzerland }\end{array}$ & $\begin{array}{l}6 \text { crops: wheat, } \\
\text { maize, barley, } \\
\text { potatoes, oilseed } \\
\text { rape, temporary } \\
\text { grassland }(2 y)\end{array}$ & $\begin{array}{l}\text { Taraxacum officinale } \\
\text { and Rumex obtusifolius } \\
\text { increased in temporary } \\
\text { grassland with time and } \\
\text { dominated the weed community } \\
\text { in the following crop }\end{array}$ & & $\begin{array}{l}\text { Taraxacum } \\
\text { officinale, } \\
\text { Rumex } \\
\text { obtusifolius }\end{array}$ \\
\hline
\end{tabular}

${ }^{1}$ FE, field experiment. ${ }^{2}$ : Forage crops are in bold.

Table II. Crop species surveyed in the three-year study, with sampling effort and survey periods.

\begin{tabular}{|c|c|c|c|c|c|c|c|c|}
\hline \multirow{2}{*}{ Crop species } & \multirow{2}{*}{ Type } & \multirow{2}{*}{ Sowing season } & \multirow{2}{*}{ Freq. ${ }^{1}$} & \multicolumn{4}{|c|}{ Number of fields surveyed } & \multirow{2}{*}{$\begin{array}{c}\text { Survey periods }^{2} \\
\text { min- } \max \end{array}$} \\
\hline & & & & 2006 & 2007 & 2008 & Total $(\%)$ & \\
\hline Alfalfa (Medicago sativa) & perennial & autumn or spring & $4 \%$ & 69 & 61 & 64 & $194(31 \%)$ & 10 April-17 May \\
\hline Winter wheat (Triticum aestivum) & annual & autumn & $38 \%$ & 98 & 61 & 78 & $237(38 \%)$ & 16 Feb.-2 May \\
\hline Oilseed rape (Brassica napus) & annual & autumn & $13 \%$ & 40 & 0 & 16 & $56(9 \%)$ & 10 Mar.- 31 Mar. \\
\hline Pea (Pisum sativum) & annual & autumn or spring & $3 \%$ & 21 & 20 & 1 & $42(7 \%)$ & 26 Mar.-23 May \\
\hline Sunflower (Helianthus annuus) & annual & spring-summer & $14 \%$ & 21 & 22 & 3 & $46(7 \%)$ & 22 May-8 July \\
\hline Maize (Zea mays) & annual & spring-summer & $9 \%$ & 21 & 22 & 0 & $43(7 \%)$ & 22 May-8 June \\
\hline Sorghum (Sorghum bicolor) & annual & spring-summer & NA & 0 & 14 & 0 & $14(2 \%)$ & 8 June-29 June \\
\hline Total & & & & 270 & 200 & 162 & $632(100 \%)$ & \\
\hline
\end{tabular}

${ }^{1}$ Approximate frequency of the crop in the study area.

2 The earliest and latest survey dates across all study years.

frequency of the crops in the region except for alfalfas, which were over-represented (Tab. II).

Weed surveys in annual crops were done in 32 quadrats of $4 \mathrm{~m}^{2}\left(2 \mathrm{~m}^{*} 2 \mathrm{~m}\right)$ per field arranged along eight transects radiating from the centre of the field. In alfalfas, surveys were realised in 30 quadrats of $0.25 \mathrm{~m}^{2}\left(0.5 \mathrm{~m}^{*} 0.5 \mathrm{~m}\right)$ which were arranged on 2-3 parallel transects covering the entire field. Field edges were avoided in both cases. Smaller plot sizes were necessary due to the higher crop vegetation density in alfalfas compared with the annual crops. A statistical method was used a posteriori to test whether the two methods captured the same percentage of species present in the fields. For each field, we calculated the ratio of the observed species richness to the expected total species richness, which was estimated by Chao's formula (Colwell and Coddington, 1994) using the 'specpool' function in the 'vegan' package (Oksanen et al., 2009) of R (R Development Core Team, 2008). The results showed that this ratio did not vary significantly between the seven crops $\left(\mathrm{F}_{6,625}=1.48, P=0.18\right)$. The mean ratios were highest in sorghum (84.0\%), lowest in wheat (76.0\%) and intermediate in alfalfa (77.3\%), suggesting that the methods captured a similar amount of information. This was also confirmed by species accumulation curves (sample-based rarefaction curves) (Gotelli and Colwell, 2001) which were calculated for the quadrats on the field scale using the 'specaccum' function of the 'vegan' package of R. The shape of the curves varied (data not shown), especially between fields with higher and lower species richness, but not between the crops, 
suggesting that the amount of information captured by both sampling techniques did not differ. Crop volunteers were not included in the analysis. 197 weed taxa were distinguished, including 161 species and 36 groupings of several species belonging to the same genera.

\subsection{Statistical analysis}

Presence-absence data from the 30-32 quadrats per field were used to calculate species frequency on the field scale. The percentage of occupied quadrats was used as an indicator of species abundance on the field scale. Different multivariate statistics and ordination methods were used to describe and test the differences between the seven crops. Rare weed species (present in less than 12 fields out of 632) were excluded from the multivariate analysis as they may unduly influence the results (Kenkel et al., 2002). As the survey year $(2006,2007,2008)$ had no strong influence on the weed communities in this dataset (data not shown), data from all three years were pooled for comparing the crops.

Canonical Discriminate Analysis (CDA, Kenkel et al., 2002), also known as "Canonical Variates Analysis" was used as a constrained ordination method to visualise the community differences between the crops. CDA finds axes that best separate predefined groups (crops) in multivariate space. Analysis of Similarities (ANOSIM, Clarke, 1993) with the Bray-Curtis dissimilarity measure was used for testing the null hypothesis that crops do not differ in their weed composition. This nonparametric method is recommended for analysing multivariate data containing many zeros and does not rely on assumptions about multivariate normality (Kenkel et al., 2002; Sosnoskie et al., 2006). The ANOSIM-R statistic varies between 0 (no differences between crops) and 1 (maximum difference, crops do not share any weed species). After the global tests, pairwise differences between all crops were calculated and Bonferronicorrected p-values are reported.

Indicator Species Analysis (ISA, Dufrene and Legendre, 1997) was used to identify and test the weed species showing strongest differences among the seven crops. This method combines information on the species frequency in each crop (presence-absence on the field scale) and on the species abundance in each crop (here: percentage of presence on the quadrats of each field). It returns indicator values (IV) for each species in each crop varying between 0 (species absent from all fields of that crop) and 100 (species is present with highest abundance in all fields of the crop, thus 'perfect indication'). These values are tested for statistical significance using a randomisation technique (4999 permutations of the fields' allocations to crops).

\section{RESULTS AND DISCUSSION}

\subsection{Weed communities}

Weed communities showed strong non-random differences between the crops (ANOSIM-R $=0.42, P<0.0001$ ).

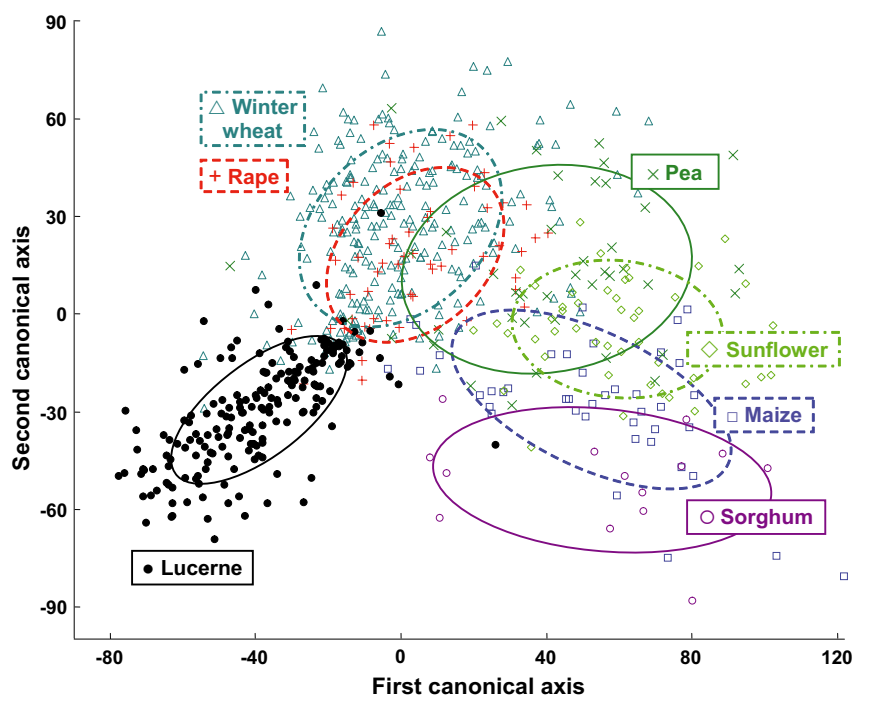

Figure 1. Canonical discriminant analysis (CDA) showing the differences in the weed communities in 7 crops: $\bullet$ alfalfa, $\triangle$ winter wheat, + oilseed rape, $\times$ pea, $\diamond$ sunflower, $\square$ maize, $\bigcirc$ sorghum (each point corresponds to one field, 632 fields in total). $60 \%$ confidence ellipses around crop centroids are drawn. Perennial alfalfas had the most distinct weed communities compared with all annual crops. Differences between autumn-sown annual crops (wheat, rape) and spring/summer-sown crops (sunflower, maize, sorghum) were also strong, while peas (sown in autumn or spring) had an intermediate position.

Canonical Discriminant Analysis (CDA) indicated that species composition mainly varied between three groups of crops: (i) perennial alfalfas, (ii) autumn-sown annual crops (wheat, oilseed rape) and (iii) spring/summer-sown annual crops (sunflower, maize, sorghum). Peas, which may be sown in autumn or spring, had an intermediate position between autumn- and spring-sown crops (Fig. 1).

Pairwise comparisons showed that the differences were strongest between alfalfa and sunflower (ANOSIM-R $=0.71$, $P<0.0001$ ), followed by alfalfa-maize, -pea, -rape, -sorghum and -wheat, while nearly all comparisons between pairs of annual crops were lower (Tab. III). This is consistent with CDA (Fig. 1). Alfalfas had thus the most distinct weed species composition among the seven crops. This difference was even more pronounced than the better-known difference between autumn- and spring/summer-sown annual crops (Tab. III), which is frequently reported in the literature (e.g. Doucet et al., 1999; Murphy et al., 2006; Fried et al., 2008). The originality of our study is the inclusion of perennial crops, which have rarely been documented for commercial fields.

\subsection{Indicator species}

The strong differences between weed communities in perennial and annual crops were caused both by significant increases in nine species in alfalfas, including Taraxacum officinale, Veronica persica, Crepis spp., Silene latifolia and 
Table III. Pairwise ANOSIM comparisons of weed communities in 7 crops (Tab. II) sorted by decreasing R-values. Pairwise differences are thus strongest between alfalfas and most annual crops although differences between pairs of annual crops are mostly significant too.

\begin{tabular}{|c|c|c|c|}
\hline \multicolumn{3}{|c|}{ Crops compared } & \multirow{2}{*}{$\begin{array}{l}\text { ANOSIM-R } \\
0.71 * * * *\end{array}$} \\
\hline Alfalfa & - & Sunflower & \\
\hline Alfalfa & - & Maize & $0.71 * * * *$ \\
\hline Alfalfa & - & Pea & $0.61 * * * *$ \\
\hline Sorghum & - & Rape & $0.60 * * * *$ \\
\hline Alfalfa & - & Rape & $0.57 * * * *$ \\
\hline Sunflower & - & Sorghum & $0.56 * * * *$ \\
\hline Maize & - & Rape & $0.56 * * * *$ \\
\hline Alfalfa & - & Sorghum & $0.53 * * * *$ \\
\hline Alfalfa & - & Wheat & $0.53 * * * *$ \\
\hline Sorghum & - & Wheat & $0.50 * * * *$ \\
\hline Sorghum & - & Pea & $0.46^{* * * *}$ \\
\hline Sunflower & - & Rape & $0.43 * * * *$ \\
\hline Maize & - & Wheat & $0.39 * * * *$ \\
\hline Pea & - & Rape & $0.32 * * * *$ \\
\hline Sunflower & - & Wheat & $0.27 * * * *$ \\
\hline Sunflower & - & Pea & $0.25 * * * *$ \\
\hline Pea & - & Maize & $0.25 * * * *$ \\
\hline Sunflower & - & Maize & $0.18 * * * *$ \\
\hline Rape & - & Wheat & $0.17 * *$ \\
\hline Sorghum & - & Maize & $0.16 \mathrm{~ns}$ \\
\hline Pea & - & Wheat & $0.05 n s$ \\
\hline
\end{tabular}

****: $P<0.0001$; **: $P<0.01$; ns: not significant. $P$-values are Bonferroni-corrected.

Capsella bursa-pastoris, while about 24 other species appeared mainly in annual crops [see Tab. IV for names and indicator values (IV) of all species in all crops]. Some weed species had relatively high frequency and abundance in several annual crops. For example, Veronica hederifolia, Galium aparine and Fallopia convolvulus were indicator species for wheat, rape and pea, and Mercurialis annua, Convolvulus arvensis and Solanum nigrum for pea, sunflower, maize and sorghum crops (Tab. IV). In contrast, almost no species had high frequency in both annual crops and perennial alfalfas except Veronica persica in alfalfa and wheat and Capsella bursa-pastoris in alfalfas and sorghum (Tab. IV).

\subsection{Differences among annual crops}

Among the annual crops, typical weed germination periods may explain large parts of the observed differences between the crops, as documented in previous studies (e.g. Roberts, 1984; Hald, 1999; Fried et al., 2008). Weed communities in rape crops (sown between August and October) were characterised by species preferentially emerging in autumn or late summer including Euphorbia helioscopia, Sinapis arvensis and Viola tricolor. Winter wheat (sown in October-November) was characterised by winter-emerging species such as Veronica hederifolia, Galium aparine and Papaver rhoeas. Peas (sown in November or February-March) were dominated by early spring-emerging species including Kickxia spuria, Polygonum aviculare and Fallopia convolvulus, and sunflower, maize and sorghum crops (sown in April-May) by late springemerging species including Amaranthus retroflexus, Setaria spp., Solanum nigrum, Chenopodium album and Polygonum persicaria (Tab. IV). It should be noted that weed surveys in the spring/summer-sown crops were conducted several weeks later in the year than all other crops (Tab. II), which could have introduced some additional differences. Conversely, the autumn-sown crops and alfalfas were surveyed during the same season.

\subsection{Differences between annual and perennial crops}

Figure 2 shows that all species with high frequency in annual crops (all 6 annual crops pooled together) are less frequent in perennial alfalfas and vice versa. While all very frequent species showed clear preferences, only a few species had similar mean frequencies in both crop types: Stellaria media and Alopecurus myosuroides (Fig. 2).

As the previous studies on weeds in perennial forage crops (Tab. I) are mostly descriptive, the following discussion about the mechanisms that may have caused the differences between the weed communities in annual and perennial crops might be somewhat speculative. Parts of the observed differences might be explained by the morphology of the weed plants that would influence the response to cutting. Previous experiments on individual plants suggest that upright broad-leaved weed species are most strongly affected by cutting, which will destroy large parts of the leaves and of the apical meristems and axial buds needed for regrowth (Meiss et al., 2008). On the contrary, meristems (and leaves) of grasses or broad-leaved species with a flat morphology or rosettes would be less affected by cutting and might regrow more easily. The present study suggests that these morphological traits of broad-leaved weeds may actually be important in field conditions, as many of the species disadvantaged by alfalfas have either an upright morphology, including Mercurialis annua, Chenopodium album, Fumaria officinalis, Sinapis arvensis and Cirsium arvense, or climb up neighbouring plants, such as Galium aparine. In contrast, several of the broad-leaved species favoured by alfalfas have rosettes, including Sonchus asper, S. oleraceus, Crepis spp., Picris spp., T. officinalis and C. bursa-pastoris.

Plant life cycle duration might also explain some of the observed differences between annual and perennial crops. On the one hand, alfalfas favoured several perennial species, which has been observed previously (Andersson and Milberg, 1996; Teasdale et al., 2004; Albrecht, 2005; Hiltbrunner et al., 2008). Slower-growing biennial or perennial species probably profited from the absence of soil tillage, which may also be the case in no-till cropping systems or in secondary succession (e.g., Zanin et al., 1997; Murphy et al., 2006). Moreover, perennial species are probably more tolerant to competition and to the repeated cuttings than most annual species. Another 
Table IV. Indicator species analysis (ISA) of the weed communities in seven crops. Only weed species with IV $\max \geqslant 20$ (maximal IV over the different crops) are shown. High indicator values (IV) are shaded in successively darker shades of grey over the three levels: IV $\geqslant 10$, IV $\geqslant 20$ and IV $\geqslant 30$. Alfalfas are associated with nine taxa. Indicator species of annual crops often show high indicator values in several annual crops, but rarely in annual and perennial crops. Alfalfas were thus characterised by a distinct weed community, suppressing many (noxious) weed species typical of different annual crops while favouring other species.

\begin{tabular}{|c|c|c|c|c|c|c|c|c|c|c|}
\hline \multirow[b]{2}{*}{ Weed species } & \multirow[b]{2}{*}{ Code } & \multicolumn{7}{|c|}{ Current crop } & \multirow[b]{2}{*}{$\begin{array}{l}\text { Crop with } \\
\text { highest IV }\end{array}$} & \multirow[b]{2}{*}{$P$} \\
\hline & & 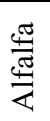 & $\frac{\vec{\Xi}}{\stackrel{\Xi}{*}}$ & 䒕 & $\mathscr{D}$ & 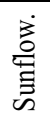 & 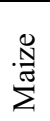 & 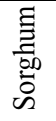 & & \\
\hline & & \multicolumn{9}{|c|}{--------------------IV-------------------- } \\
\hline Taraxacum officinale & TAROF & 47 & 4 & 0 & 0 & 0 & 0 & 7 & Alfalfa & 0.0002 \\
\hline Veronica persica & VERPE & 39 & 12 & 1 & 3 & 1 & 3 & 6 & Alfalfa & 0.0002 \\
\hline Crepis sancta + vesicaria + sp. & CVP & 34 & 0 & 3 & 0 & 0 & 0 & 0 & Alfalfa & 0.0002 \\
\hline Veronica arvensis + polita & VERAR & 32 & 3 & 0 & 1 & 0 & 0 & 0 & Alfalfa & 0.0002 \\
\hline Silene latifolia & MELAL & 25 & 2 & 1 & 2 & 1 & 1 & 1 & Alfalfa & 0.0010 \\
\hline Myosotis arvensis $+\mathrm{sp}$. & MYOAR & 22 & 4 & 3 & 1 & 0 & 0 & 0 & Alfalfa & 0.0020 \\
\hline Cerastium arvense + glomeratum & CER & 20 & 1 & 0 & 0 & 0 & 0 & 0 & Alfalfa & 0.0014 \\
\hline Poa trivialis & POATR & 20 & 3 & 0 & 1 & 0 & 1 & 3 & Alfalfa & 0.0026 \\
\hline Capsella bursa pastoris & СAPBP & 22 & 1 & 8 & 1 & 0 & 0 & 20 & Alfalfa & 0.0026 \\
\hline Papaver rhoeas + argemone + sp. & PAPRH & 4 & 20 & 2 & 3 & 0 & 0 & 0 & Wheat & 0.0070 \\
\hline Veronica hederifolia & VERHE & 3 & 32 & 17 & 19 & 0 & 0 & 0 & Wheat & 0.0002 \\
\hline Galium aparine & GALAP & 2 & 20 & 11 & 13 & 4 & 0 & 0 & Wheat & 0.0080 \\
\hline Viola arvensis + tricolor + sp. & VIOTR & 1 & 14 & 23 & 14 & 2 & 0 & 0 & Rape & 0.0022 \\
\hline Sinapis arvensis & SINAR & 1 & 6 & 27 & 4 & 9 & 2 & 4 & Rape & 0.0008 \\
\hline Euphorbia helioscopia & ЕPHHE & 0 & 1 & 32 & 3 & 15 & 3 & 6 & Rape & 0.0002 \\
\hline Reseda lutea + sp. & RES & 1 & 0 & 25 & 1 & 10 & 0 & 1 & Rape & 0.0004 \\
\hline Fallopia convolvulus & POLCO & 1 & 16 & 13 & 28 & 18 & 6 & 2 & Pea & 0.0002 \\
\hline Polygonum aviculare & POLAV & 1 & 11 & 5 & 20 & 4 & 14 & 14 & Pea & 0.0140 \\
\hline Kickxia spuria +sp. & KICSP & 0 & 0 & 0 & 40 & 1 & 6 & 12 & Pea & 0.0002 \\
\hline Senecio vulgaris $+\mathrm{sp}$ & SENVU & 4 & 6 & 9 & 8 & 32 & 1 & 3 & Sunflower & 0.0002 \\
\hline Solanum nigrum + sp. & SOLNI & 0 & 0 & 0 & 14 & 25 & 9 & 21 & Sunflower & 0.0002 \\
\hline Mercurialis annua & MERAN & 0 & 5 & 10 & 16 & 24 & 19 & 14 & Sunflower & 0.0006 \\
\hline Convolvulus arvensis & CONAR & 3 & 3 & 0 & 12 & 22 & 26 & 22 & Maize & 0.0008 \\
\hline Chenopodium album & CHEAL & 0 & 4 & 1 & 17 & 8 & 11 & 36 & Sorghum & 0.0002 \\
\hline Setaria viridis + verticillata + sp. & SET & 0 & 0 & 0 & 0 & 2 & 20 & 42 & Sorghum & 0.0002 \\
\hline Polygonum persicaria & POLPE & 0 & 0 & 0 & 2 & 5 & 18 & 20 & Sorghum & 0.0006 \\
\hline Amaranthus retroflexus & AMARE & 0 & 0 & 0 & 0 & 1 & 6 & 58 & Sorghum & 0.0002 \\
\hline Verbena officinalis $+\mathrm{sp}$ & VEBOF & 3 & 0 & 0 & 0 & 0 & 0 & 35 & Sorghum & 0.0002 \\
\hline Picris echioides & PICEC & 11 & 0 & 4 & 0 & 0 & 0 & 34 & Sorghum & 0.0002 \\
\hline Calystegia sepium & CAGSE & 0 & 0 & 0 & 0 & 0 & 9 & 30 & Sorghum & 0.0002 \\
\hline Echinochloa crus galli & ECHCG & 0 & 0 & 0 & 0 & 1 & 8 & 28 & Sorghum & 0.0002 \\
\hline Plantago major & PLAMA & 0 & 0 & 0 & 1 & 0 & 1 & 26 & Sorghum & 0.0002 \\
\hline Cirsium arvense + sp. & CIRAR & 2 & 7 & 4 & 5 & 8 & 3 & 21 & Sorghum & 0.0062 \\
\hline
\end{tabular}

mechanism might be seed predation, which may have stronger impacts on populations of annual species than on perennials and which may be particularly strong in untilled perennial crops with permanent vegetation cover (Westerman et al., 2005). While the perennial species found in alfalfas did not appear with high frequency in any annual crop, other perennial species appeared in sorghum crops including Verbena officinalis, Picris echioides, Calystegia sepium, Plantago major and Cirsium arvense (Tab. IV). This might have been caused by lower competition, lower herbicide use or no-till practices in sorghum, but information on management details is lacking. However, it indicates that some perennial species are not favoured in alfalfa. The suppressive potential of alfalfas against $C$. arvense has already been observed by previous studies (Ominski et al., 1999). Thistles are probably less affected by soil tillage in annual crops compared with other perennial species (due to the ability to regenerate from root fragments). In contrast, they may particularly suffer from the 


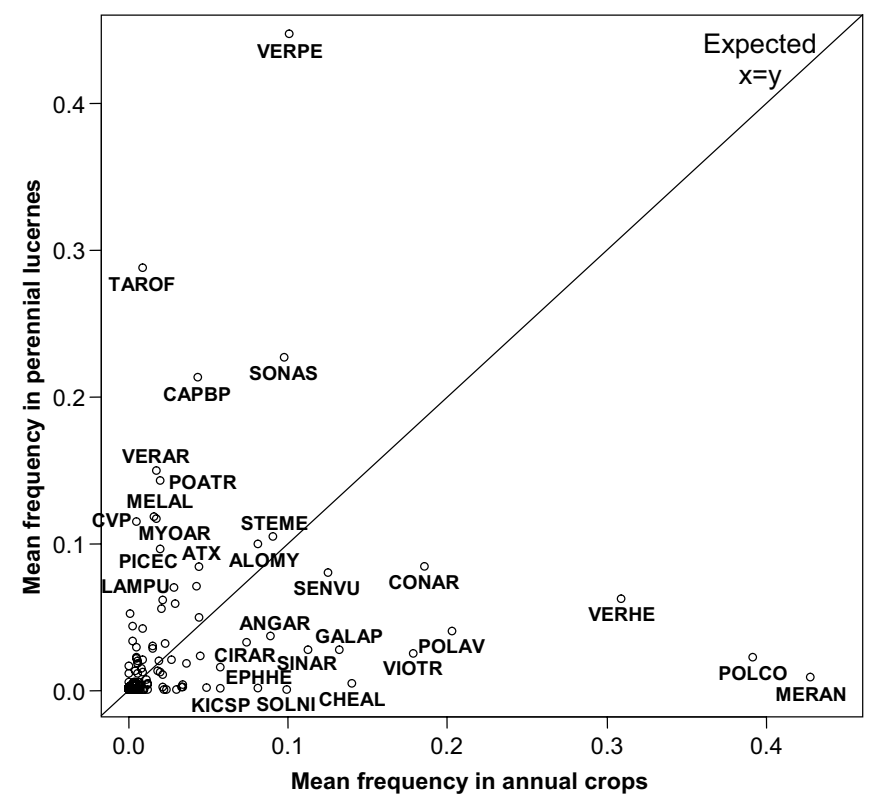

Figure 2. Weed species occurrence in six annual crops (winter wheat, rape, maize, sunflower, pea and sorghum) and in perennial alfalfa crops. Frequency varies between 0 (completely absent in all fields of that group of crops) and 1 (present in all quadrats of all fields). All frequent weed species preferred either annual or perennial crops. SONAS, Sonchus asper; STEME, Stellaria media; ALOMY, Alopecurus myosuroides; ANGAR, Anagallis arvensis; ATX, Atrilex spp.; LAMPU, Lamium purpureum; see Table IV for other species names. Rare taxa are not named in the figure.

high competition and the repeated cuttings in alfalfas depleting their belowground carbohydrate resources needed for regrowth (Graglia et al., 2006).

Besides some perennials including T. officinale, Crepis spp. and Silene latifolia, alfalfas also favoured a few small annual species with a very short life cycle such as Calepina irregularis, C. bursa-pastoris and V. persica. Short life cycles might allow species to produce seeds before the first or between two successive cuttings. Alfalfas might thus generate 'divergent selection pressures' favouring both long and very short life cycles.

\section{CONCLUSION}

This study was based on commercial fields from a large area. The advantage of analysing data from real farming systems comes at the cost of various uncontrolled factors (crop management, environmental factors and local weed species pool) that may increase the noise in the data. Despite this noise, we detected strong differences in the weed composition between 6 annual crops and perennial alfalfas. Perennial alfalfas were characterised by reduced abundance of many annual species and some perennials including Cirsium arvense that are often problematic weeds in annual crops. In parallel, alfalfas showed increased frequency of some perennial and some short-lived annual species. Several differences between annual and perennial crops including the absence of soil tillage, the increased competition and the frequent hay cuttings may be responsible for these strong weed community shifts. The relative importance of these factors should be determined by more detailed experimental studies.

This strong differentiation of plant communities confirms previous experimental studies and suggests that the diversification of crop rotations with perennial crops could contribute to Integrated Weed Management and herbicide use reduction. While alfalfas hinder the development of several weeds species that are problematic in annual crops, they may maintain a certain abundance and diversity of other wild plant species that may provide trophic resources for animals and other ecosystem services (Gerowitt et al., 2003; Marshall et al., 2003; Holland et al., 2006). The strong impacts of perennial crops on weed communities reported in this paper should be completed by long-term studies tracking the weed community during entire crop rotations.

Acknowledgements: We thank Laurent Grelet, Anne-Caroline Denis, Damien Charbonnier, Luc Bianchi, Dominique Le Floch, Fabrice Dessaint, Bruno Chauvel, François Bretagnolle, Émilie Cadet, Jacques Gasquez and Florence Strbik for participation in the field surveys; Jacques Gasquez for help with weed taxonomy; Pablo Inchausti, Vincent Bretagnolle, Alban Thomas and Rodolphe Bernard for database maintenance, Fabrice Dessaint and Ralf Schmiele for statistical advice, and Richard Gunton and Antoine Gardarin for corrections and helpful comments. This work was funded by ECOGER, SYSTERRA and AgroSupDijon, and supported by a PhD scholarship from the French research ministry to H.M.

\section{REFERENCES}

Albrecht H. (2005) Development of arable weed seedbanks during the 6 years after the change from conventional to organic farming, Weed Res. 45, 339-350.

Andersson T.N., Milberg P. (1996) Weed performance in crop rotations with and without leys and at different nitrogen levels, Ann. Appl. Biol. 128, 505-518.

Andersson T.N., Milberg P. (1998) Weed flora and the relative importance of site, crop, crop rotation, and nitrogen, Weed Sci. 46, 30-38.

Bellinder R.R., Dillard H.R., Shah D.A. (2004) Weed seedbank community responses to crop rotation schemes, Crop Prot. 23, 95-101.

Belyea L.R., Lancaster J. (1999) Assembly rules within a contingent ecology, Oikos 86, 402-416.

Cardina J., Herms C.P., Doohan D.J. (2002) Crop rotation and tillage system effects on weed seedbanks, Weed Sci. 50, 448-460.

Cavigelli M.A., Teasdale J.R. , Conklin A.E. (2008) Long-term agronomic performance of organic and conventional field crops in the mid-Atlantic region, Agron. J. 100, 785-794.

Clarke K.R. (1993) Non-parametric multivariate analyses of changes in community structure, Austral Ecol. 18, 117-143.

Clay S.A., Aguilar I. (1998) Weed seedbanks and corn growth following continuous corn or alfalfa, Agron. J. 90, 813-818.

Colwell R.K., Coddington J.A. (1994) Estimating terrestrial Biodiversity through extrapolation, Philos. T. Roy. Soc. B 345, 101-118. 
Doucet C., Weaver S.E., Hamill A.S., Zhang J.H. (1999) Separating the effects of crop rotation from weed management on weed density and diversity, Weed Sci. 47, 729-735.

Dufrene M., Legendre P. (1997) Species assemblages and indicator species: The need for a flexible asymmetrical approach, Ecol. Monogr. 67, 345-366.

Entz M.H., Baron V.S., Carr P.M., Meyer D.W., Smith S.R., McCaughey W.P. (2002) Potential of forages to diversify cropping systems in the northern Great Plains, Agron. J. 94, 240-250.

Entz M.H., Bullied W.J., KatepaMupondwa F. (1995) Rotational benefits of forage crops in Canadian prairie cropping systems, J. Prod. Agric. 8, 521-529.

Freyer B. (2003) Fruchtfolgen Ulmer, Stuttgart-Hohenheim, Germany.

Fried G., Norton L.R., Reboud X. (2008) Environmental and management factors determining weed species composition and diversity in France, Agr. Ecosys. Environ. 128, 68-76.

Gerowitt B., Bertke E., Hespelt S.K., Tute. C. (2003) Towards multifunctional agriculture - weeds as ecological goods? Weed Res. 43, $227-$ 235 .

Gill G.S., Holmes J.E. (1997) Efficacy of cultural control methods for combating herbicide-resistant Lolium rigidum, Pestic. Sci. 51, $352-358$.

Gosse G., Lemaire G., Chartier M., Balfourier F. (1988) Structure of a lucerne population (Medicago sativa L.) and dynamics of stem competition for light during regrowth, J. Appl. Ecol. 25, 609-617.

Gotelli N.J., Colwell R.K. (2001) Quantifying biodiversity: procedures and pitfalls in the measurement and comparison of species richness, Ecol. Lett. 4, 379-391.

Graglia E., Melander B., Jensen R.K. (2006) Mechanical and cultural strategies to control Cirsium arvense in organic arable cropping systems, Weed Res. 46, 304-312.

Hald A.B. (1999) The impact of changing the season in which cereals are sown on the diversity of the weed flora in rotational fields in Denmark, J. Appl. Ecol. 36, 24-32.

Heggenstaller A.H., Liebman M. (2006) Demography of Abutilon theoprasti and Setaria faberi in three crop rotation systems, Weed Res. $46,138-151$

Hiltbrunner J., Scherrer C., Streit B., Jeanneret P., Zihlmann U., Tschachtli R. (2008) Long-term weed community dynamics in Swiss organic and integrated farming systems, Weed Res. 48, 360-369.

Holland J.M., Hutchison M.A.S., Smith B., Aebischer N.J. (2006) A review of invertebrates and seed-bearing plants as food for farmland birds in Europe, Ann. Appl. Biol. 148, 49-71.

Huarte H.R., Arnold R.L.B. (2003) Understanding mechanisms of reduced annual weed emergence in alfalfa, Weed Sci. 51, 876-885.

Katsvairo T.W., Wright D.L., Marois J.J., Hartzog D.L., Rich J.R., Wiatrak P.J. (2006) Sod-Livestock Integration into the PeanutCotton Rotation: A Systems Farming Approach, Agron. J. 98, 1156-1171.

Kenkel N.C., Derksen D.A., Thomas A.G., Watson P.R. (2002) Multivariate analysis in weed science research, Weed Sci. 50, 281-292.

Khanh T.D., Chung M.I., Xuan T.D., Tawata S. (2005) The Exploitation of Crop Allelopathy in Sustainable Agricultural Production, J. Agron. Crop Sci. 191, 172-184.
Liebman M., Davis A.S. (2000) Integration of soil, crop and weed management in low-external-input farming systems, Weed Res. 40, $27-47$.

Liebman M., Dyck E. (1993) Crop-Rotation and Intercropping Strategies for Weed Management, Ecol. Appl. 3, 92-122.

Marshall E.J.P., Brown V.K., Boatman N.D., Lutman P.J.W., Squire G.R., Ward L.K. (2003) The role of weeds in supporting biological diversity within crop fields, Weed Res. 43, 77-89.

Meiss H., Munier-Jolain N., Henriot F., Caneill J. (2008) Effects of biomass, age and functional traits on regrowth of arable weeds after cutting, J. Plant Dis. Prot. XXI, 493-499.

Murphy S.D., Clements D.R., Belaoussoff S., Kevan P.G., Swanton C.J. (2006) Promotion of weed species diversity and reduction of weed seedbanks with conservation tillage and crop rotation, Weed Sci. $54,69-77$.

Nazarko O.M., Van Acker R.C., Entz M.H. (2005) Strategies and tactics for herbicide use reduction in field crops in Canada: A review, Can. J. Plant Sci. 85, 457-479.

Norris R.F., Ayres D. (1991) Cutting Interval and Irrigation Timing in Alfalfa: Yellow Foxtail Invasion and Economic Analysis, Agron. J. $83,552-558$.

Oksanen J., Kindt R., Legendre P., O’Hara B., Simpson G.L., Solymos P., Stevens M.H.H., Wagner H. (2009) vegan: Community Ecology Package, R package version 1.15-3.

Ominski P.D., Entz M.H., Kenkel N. (1999) Weed suppression by Medicago sativa in subsequent cereal crops: a comparative survey, Weed Sci. 47, 282-290.

R Development Core Team (2008) R: A Language and Environment for Statistical Computing, R Foundation for Statistical Computing, Vienna.

Roberts H.A. (1984) Crop and weed emergence patterns in relation to time of cultivation and rainfall, Ann. Appl. Biol. 105, 263-275.

Schoofs A., Entz M.H. (2000) Influence of annual forages on weed dynamics in a cropping system, Can J. Plant Sci. 80, 187-198.

Sjursen H. (2001) Change of the weed seed bank during the first complete six-course crop rotation after conversion from conventional to organic farming, Biol. Agric. Hortic. 19, 71-90.

Smith R.G., Gross K.L. (2007) Assembly of weed communities along a crop diversity gradient, J. Appl. Ecol. 44, 1046-1056.

Sosnoskie L.M., Herms N.P., Cardina J. (2006) Weed seedbank community composition in a 35 -yr-old tillage and rotation experiment, Weed Sci. 54, 263-273.

Teasdale J.R., Mangum R.W., Radhakrishnan J., Cavigelli M.A. (2004) Weed seedbank dynamics in three organic farming crop rotations, Agron. J. 96, 1429-1435.

Tilman D., Hill J., Lehman C. (2006) Carbon-Negative Biofuels from Low-Input High-Diversity Grassland Biomass, Science 314, 1598-1600.

Westerman P.R., Liebman M., Menalled F.D., Heggenstaller A.H., Hartzler R.G., Dixon P.M. (2005) Are many little hammers effective? - Velvetleaf (Abutilon theophrasti) population dynamics in two- and four-year crop rotation systems, Weed Sci. 53, 382-392.

Zanin G., Otto S., Riello L., Borin M. (1997) Ecological interpretation of weed flora dynamics under different tillage systems, Agr. Ecosys. Environ. 66, 177-188. 